\title{
Growth and length-weight relationships of Gambusia affinis (Baird et Girard, 1853) population in Algeria (Cyprinodontiformes Poeciliidae)
}

\author{
Naima Sellaoui ${ }^{*}$ \& Farid Bounaceur ${ }^{2}$ \\ ${ }^{1}$ Faculty of Sciences of Nature and Life, Laboratory of Agrobiotechnology and Nutrition in Semi-arid \\ Zone, Ibn-Khaldoun University of Tiaret, 14000, Algeria \\ ${ }^{2}$ Department of Natural Sciences and Life, University Center of Tismessilt, 38000 Algeria \\ *Corresponding author: naimaselb@yahoo.fr
}

\begin{abstract}
The aim of this study is to provide necessary information on the growth, length-weight relationships of Gambusia affinis (Baird et Girard, 1853) (Cyprinodontiformes Poeciliidae) in four different areas: Timimoune's foggara, southwestern Algerian Sahara, with a total of 402 specimens; 182 fishes in Bechar; Biskra, northeastern Sahara, with 282 specimens; and Oued Sebaine, in western Algeria, with 638 fishes. The female to male sex ratio was 2.14:1 (Timimoune), 2.19:1 (Bechar), 2.61:1 (Biskra) and 2.35:1 (Tiaret). The length-weight relationship of $G$. affinis population shows a difference in growth between the sexes (isometric, positive and negative allometric). The parameter of Von Bertalanffy, L $\infty$, was obtained for the females of each region: in Timimoune, $62.14 \mathrm{~mm}$; in Bechar, $51.72 \mathrm{~mm}$; in Biskra, 67.25 $\mathrm{mm}$; and in Tiaret, $63.62 \mathrm{~mm}$. The L $\infty$ of males for each region is instead: in Timimoune, $45.48 \mathrm{~mm}$; in Bechar, $41.75 \mathrm{~mm}$; in Biskra, $47.89 \mathrm{~mm}$; and in Tiaret, $45.49 \mathrm{~mm}$.
\end{abstract}

KEY WORDS Algerian; Gambusia affinis; sex ratio; length-weight; Von Bertalanffy.

Received 12.08.2020; accepted 22.11.2020; published online 23.12.2020

\section{INTRODUCTION}

The birth rate, death rate, population size, density, age structure and sex ratio of population are parameters particularly important that influence population growth or decline (Dodge, 2006). The allocation of energy to growth and reproduction, in relation to temperature and food availability. Vondracek et al. (1988), investigated in laboratory experiments with Gambusia affinis (Baird et Girard, 1853). The growth rates of this specie in a cycling temperature regime (20-30 ${ }^{\circ} \mathrm{C}$, were faster than in a $25^{\circ} \mathrm{C}$ constant temperature, and a negative relationship between growth rate and fish density (Stearns \& Sage, 1980).
Gambusia affinis is the most abundant, widespread freshwater fish in the world (Pyke, 2008), it belongs to Poeciliidae family and Cyprinodontiformes order. Originally, it comes from the eastern and south-eastern United State of America, ranging from New Jersey to central Mexico, it has, however, been successfully introduced to most of the world, except Antarctica (Pyke, 2008). In Algeria, G. affinis is considered as a species exotic, it was mentioned in the works of zoologist Seurat, declaring the introduction of this species in Algeria since 1924 (Arab, 1989). This species is considered as a biological control agent to eradicate mosquitoes and the disease vectors they harbor (Green \& Imber, 
1977; Nelson \& Keenan, 1992; Offill \& Walton, 1999), it is therefore successful in controlling malaria (Krumholz, 1948; Walton, 2007).

This species is a hardy fish which is tolerant to a wide range of water quality parameters, including elevated salinity (Alcaraz \& García Berthou, 2007). Gambusia affinis from Texas grew more slowly in fresh water rather than in brackish water (Stearns $\&$ Sage, 1980), and survives in waters with very low oxygen (Cech et al., 1985), and high temperatures (Pyke, 2005)

The overall aim of this study is to provide original information for the first time on some parameters, such as the length population structure or frequency distribution, length-weight relationship, age and the growth parameters of Von Bertalanffy of the $G$. affinis population in four Algerian biotopes, such as the west, the northeast and the southwest of the Algerian Sahara and compare these results with other studies on mosquitofish. Note that knowledge of these biological characteristics and the length-weight relationships is very important for the assessment and management of fish stocks (Cai et al., 2019).

\section{MATERIAL AND METHODS}

\section{Study area}

All specimens were collected from four different areas (Fig. 1).

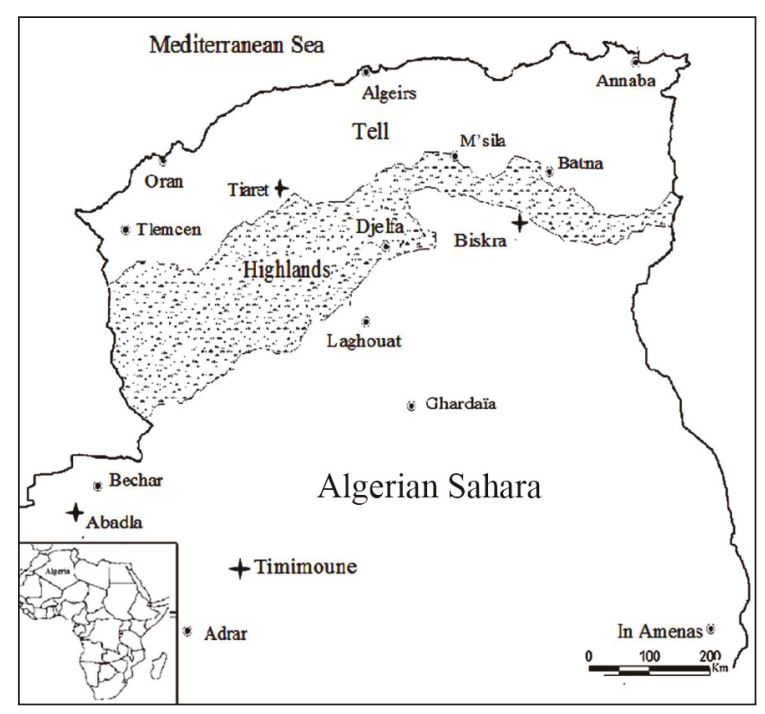

Figure 1. Geographical location of the study area.
Gazelle fountain dam in Biskra $\left(35^{\circ} 7^{\prime} 25.52^{\prime \prime} \mathrm{N}\right.$ and 5'35'25.04”E). It is located at $37 \mathrm{~km}$ from governorate Biskra (the Ziban), in the northeastern of the Algerian Sahara, at the southern foothills of the Saharan Atlas. The mountains at the northern limit mitigate the extension of the influences of the humid Mediterranean climate and give the region a hyper arid character towards the Sahara to the south. The data show that the coldest month is December with an average temperature of $12.2^{\circ} \mathrm{C}$, and the hottest month is August with $34.7^{\circ} \mathrm{C}$.

Oued Sebaine in Tiaret $\left(35^{\circ} 26^{\prime} 18.01^{\prime \prime} \mathrm{N}\right.$ and $1^{\circ} 36^{\prime} 31.09$ ' $\left.\mathrm{E}\right)$. It is located in north-western of Algeria, $28 \mathrm{~km}$ the east of the governorate Tiaret, at an altitude of $918 \mathrm{~m}$, it is small river that has a ten of permanent sources of fresh water, s'called Ras El Ain, about $1.4 \mathrm{~km}$ of long, it poured into the Ouassel river. The continental climate has two periods: a harsh winter with an average temperature of $6{ }^{\circ} \mathrm{C}$ in January and a hot and dry summer at 34.9 ${ }^{\circ} \mathrm{C}$ in July. This wadi is a habitat of high terrestrial and aquatic biodiversity.

The Timimoune's foggarain Adrar $\left(29^{\circ} 15^{\prime} 13\right.$. $58^{\prime} \mathrm{N}$ and $\left.0^{\circ} 12^{\prime} 35.19^{\prime \prime} \mathrm{E}\right)$. Situated in the western Algerian Sahara, Igraven and Abad are the sampling sites of fish in Timimoune about $200 \mathrm{~km}$ northeast of Adrar governate, at $257 \mathrm{~m}$ altitude. The foggara is a draining underground tunnel dug in a straight line from upstream to downstream, which collects and brings underground water to the land to be irrigated. The Saharan climate is characterized by a very irregular and weak rain, with an average temperature of $13.2^{\circ} \mathrm{C}$ in January, and $37.5^{\circ} \mathrm{C}$ in July.

The small dam in Abadla, Bechar $\left(31^{\circ} 01^{\prime} 13^{\prime \prime} \mathrm{N}\right.$ and $\left.02^{\circ} 43^{\prime} 14^{\prime \prime} \mathrm{W}\right)$. It is located in the southwest of Algeria, at $950 \mathrm{~km}$ from the capital Algiers, the small dam is a part of the Oued Guir which originates in the High Atlas in Morocco and travels to the border between Algeria and Morocco, feeds the Djorf Torba dam (50 km west of Bechar), then crosses the town of Abadla. The Saharan climate is characterized by a very hot summer and a very cold winter, light precipitation, frequent and violent winds.

\section{Sampling}

Monthly samples were collected for each area, a total of 282 specimens of G. affinis during the period from November 2006 to May 2007 at the Gazelle fountain dam in Biskra, 402 specimens 
were collected from July 2010 to June 2011 in Timimoune's foggara, 638 fish were collected in wadi Sebaine from March 2017 to February 2018, and 182 mosquitofish were collected between May 2018 and October 2018 in the small dam in Abadla, Bechar, where the sampling stopped due to a flood. All the sampled fish were caught during the day using a dip net (a stretched size of $1 \mathrm{~mm}$ ). The biological material was preserved in a $4 \%$ formalin solution and sent to the laboratory, where the total length (Lt) was measured by a digital calliper (to the nearest 0.01 millimeters) and the weight by a digital precision balance (to the nearest 0.01 grams). The sex was determined from the morphology of the anal fin, which takes a gonopodium form, and by direct observation of the gonad structure.

The test of reduced gap $\varepsilon$ used for the comparison of the average sizes of males and females (Schwartz, 1983) followed this equation:

$$
\varepsilon=\frac{\left|\overline{X_{1}}-\overline{X_{2}}\right|}{\sqrt{\frac{\sigma_{1}^{2}}{n_{1}}+\frac{\sigma_{2}{ }^{2}}{n_{2}}}}
$$

Where $\sigma_{1}{ }^{2}$ : variance of females; $\sigma_{2}^{2}$ : variance of males; $X_{1}$ : denotes mean female; $X_{2}$ : denotes mean male; $n_{1}$ : number of females; and $n_{2}$ : number of males.

\section{Length-weight relationship}

The length-weight relationship was calculated for both sexes using the allometric equation (Le Cren, 1951): $\mathrm{Wt}=\mathrm{a} \times \mathrm{Lt}^{\mathrm{b}}$.

Where Wt is the body weight $(\mathrm{g}), \mathrm{Lt}$ is the total length ( $\mathrm{mm})$, $\mathrm{a}$ is the regression and $\mathrm{b}$ is the regression coefficient (slope), The parameters $a$ and $b$ were estimated by linear regression analysis by logarithmic transformed (Froese, 2006) as follows: $\log (\mathrm{Wt})=\log (\mathrm{a})+\mathrm{b} \times \log (\mathrm{Lt})$.

If $b=3$ the growth is isometric, if $b<3$ the allometry is negative and if $b>3$ the allometry is positive.

\section{Growth parameters}

The growth model used for the fish growth is that of Von Bertalanffy (1938), according to the following equation : $\mathrm{Lt}=\mathrm{L}_{\infty}\left(1-\mathrm{e}^{-\mathrm{K}(\mathrm{t}-\mathrm{t} 0)}\right)$.

Where $\mathrm{L}_{\infty}$ is the asymptotic total length, $\mathrm{Lt}$ is the total length in $\mathrm{mm}$ at age $\mathrm{t}, \mathrm{K}$ is the growth coefficient and $t 0$ is the hypothetical age at which length is zero.

\section{Statistical processing}

The growth parameters of the Von Bertalanffy equation were estimated by the ELEFFAN method (Electronic length-frequency analysis) of the LFDA software (length frequency distribution analysis) (Kirkwood et al., 2001).

The growth performance index $\Phi$ 'proposed by Pauly and Munro (1984), was calculated using the following formula: $\Phi^{\prime}=\log (\mathrm{K})+2 \times \log (\mathrm{L} \infty)$.

\section{RESULTS}

\section{Population structure and Length frequency distri- bution}

The population of $G$. affinis presents in Biskra consists of 282 individuals, 204 females (72.34\%) and 78 males $(27.65 \%)$, in Timimoune 402 fish were captured, 274 females $(63.11 \%)$ and 128 males $(36.88 \%)$, in Tiaret 638 mosquitofish were captured, 448 females (70.21\%) and 190 males $(36.88 \%)$, and in Bechar 182 fish were captured, 125 females $(68.68 \%)$, and 57 males $(31.31 \%)$. Therefore, the overall sex ratio (F:M) of G. affinis for each area is in favor of females rather than males: Biskra, 2.61:1; Timimoune, 2.14:1; Tiaret, 2.35:1; and Bechar, 2.19:1. These values were significantly different from $1: 1$.

The length of G. affinis females and males in Biskra ranged, respectively, from $19.01 \mathrm{~mm}$ to $64.02 \mathrm{~mm}$ and from $21.9 \mathrm{~mm}$ to $45.07 \mathrm{~mm}$. In Tiaret the minimum and maximum size of females and males ranged, respectively, from 16.6 to 60.20 $\mathrm{mm}$ and from 18.7 to $43.07 \mathrm{~mm}$. In the population of Timimoune the total length of the females and males were, respectively, from $19.01 \mathrm{~mm}$ to $59 \mathrm{~mm}$ and from $21 \mathrm{~mm}$ to $43 \mathrm{~mm}$. Lastly, the length of the population of females and males in Bechar ranged, respectively, from $16.7 \mathrm{~mm}$ to $49.10 \mathrm{~mm}$ and from $19.73 \mathrm{~mm}$ to $38.05 \mathrm{~mm}$.

The calculated values of the reduced gap $\varepsilon$ for our study are 3.62 (in Biskra), 11.94 (in Timimoune), 4.11 (in Tiaret) and 4.97 (in Bechar). These values are higher than the value given to the Gaussian distribution Table (1.96) for a confidence level of $5 \%$ indicating that the average sizes of females is significantly larger than that observed for males.

Figure 2 shows in Timimoune that there are more 


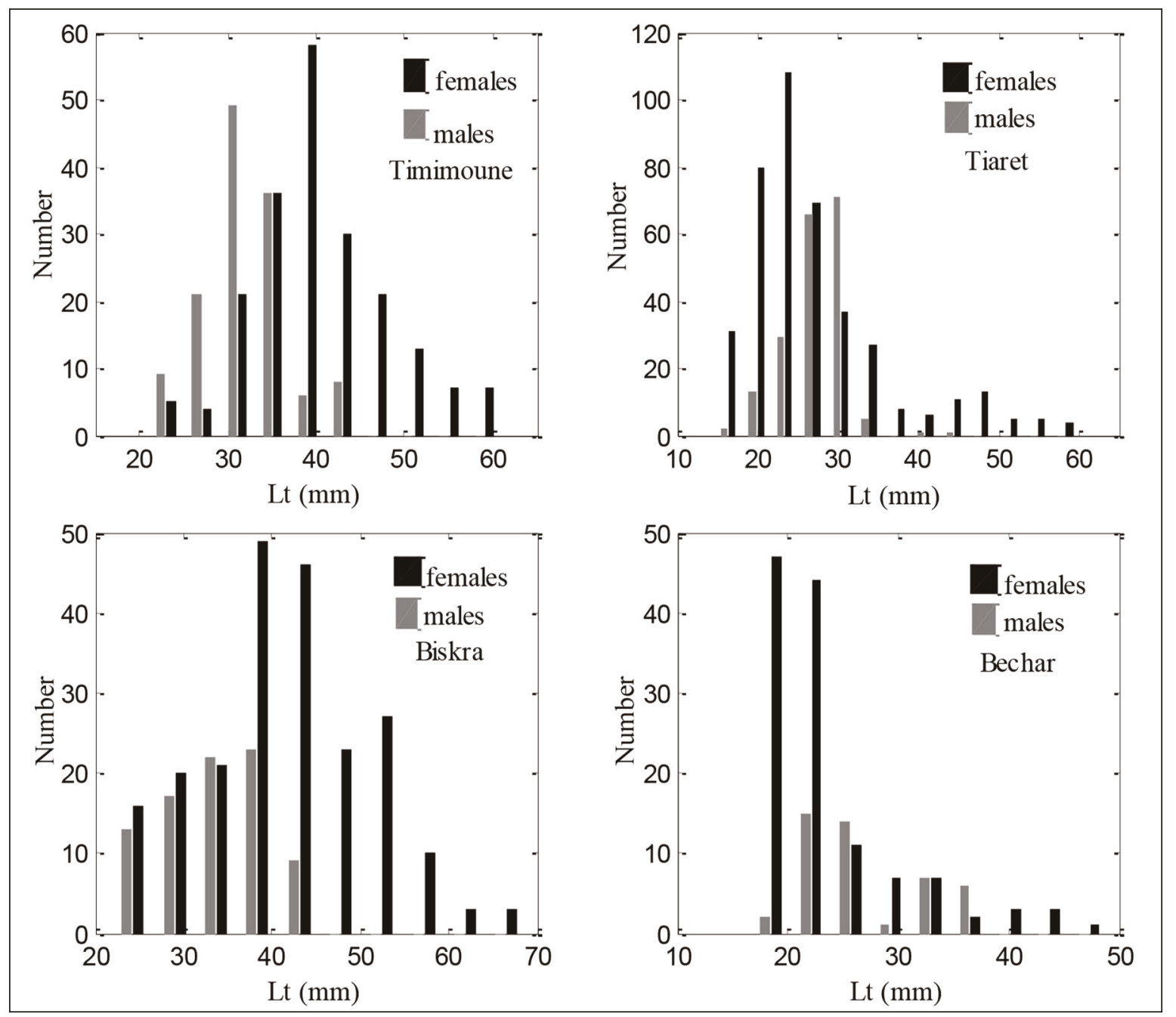

Figure 2. Length composition of Gambusia affinis from each region.

females than males in all size groups except 23.01 $\mathrm{mm}$ (5 females/9 males), $27.01 \mathrm{~mm}$ (4 females/21 males) and $31.01 \mathrm{~mm}$ (21 females/49 males). In Tiaret the females were more than males in all size groups except $30.35 \mathrm{~mm}$ (37 females/71 males), hence in Biskra and Bechar, females were generally the most abundant in all sizes, while males of Bechar predominated in sizes $25.7 \mathrm{~mm}$ (11 females/14 males) and $36.5 \mathrm{~mm}$ ( 2 females/6 males).

\section{Length-weight relationship}

Length-weight relationship of $G$. affinis is illustrated in figures 3, 4, 5 and 6 which show a negative allometry growth observed for males of Timimoune $(b=2.82)$, Tiaret $(b=2.81)$ and Bechar $(b=2.84)$, and a positive allometric for females of Biskra $(b=$ 3.19), Timimoune $(b=3.07)$ and Tiaret $(b=3.32)$, and isometric growth for males of Biskra $(b=3.00)$ and females of Bechar $(b=3.04)$. All linear regressions of the length-weight relationships were very significant, with the coefficient of determination $\left(\mathrm{r}^{2}\right)$ of Biskra, 0.980 for females and 0.928 for males, of Timimoune, 0.897 for females and 0.906 for males, of Tiaret, 0.986 for females and 0.925 for males, and of Bechar, 0.963 for females and 0.952 for males, with $(\mathrm{p}<0.05)$.

All available data on the Von Bertalanffy growth equation and $\Phi$ ' values of the $G$. affinis population from the present study are compiled in Table 1, in which the $\Phi$ ' index shows a great similarity between the two sexes. 


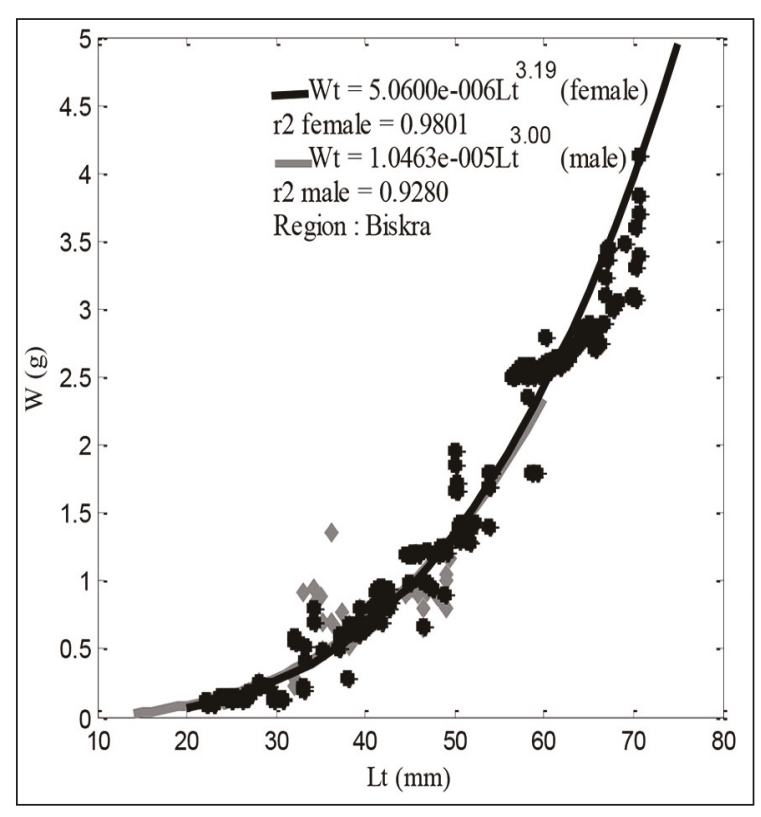

Figure 3. Length-weight relationship of male and female Gambusia affinis at Biskra.

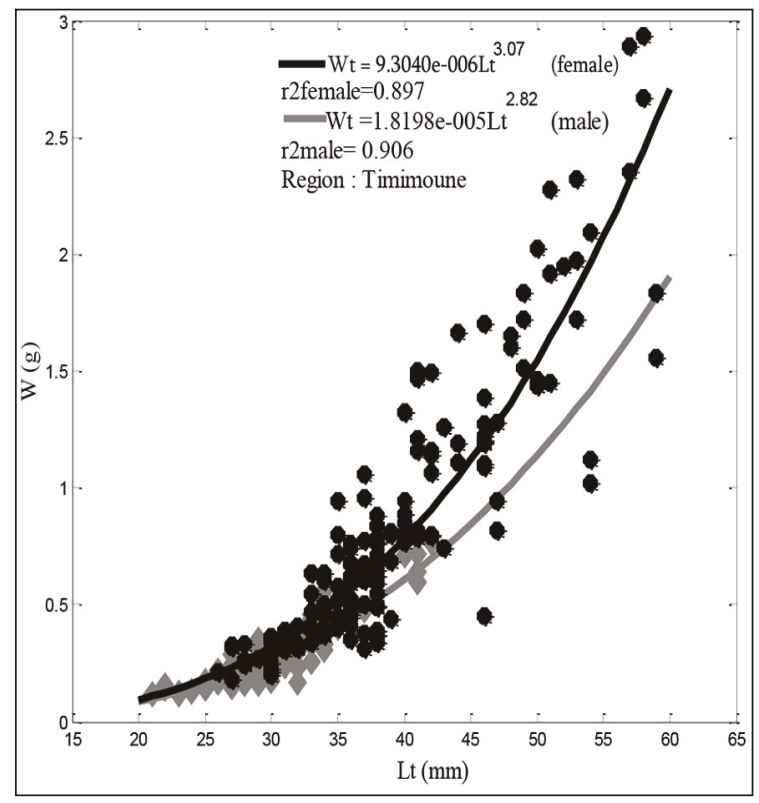

Figure 4. Length-weight relationship of male and female Gambusia affinis at Timimoune.

\section{DISCUSSION}

The overall sex ratio of G. affinis (F: M) in the four populations of Biskra, Timimoune, Tiaret and Bechar was significantly different from a 1:1 in favor of females, as confirmed in previous works by

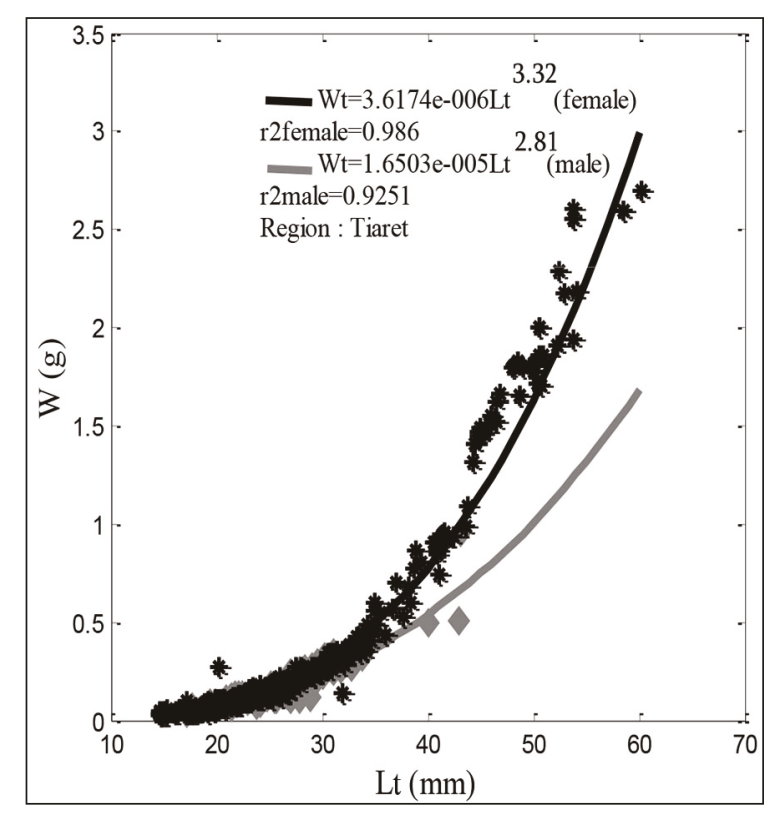

Figure 5. Length-weight relationship of male and female Gambusia affinis at Tiaret.

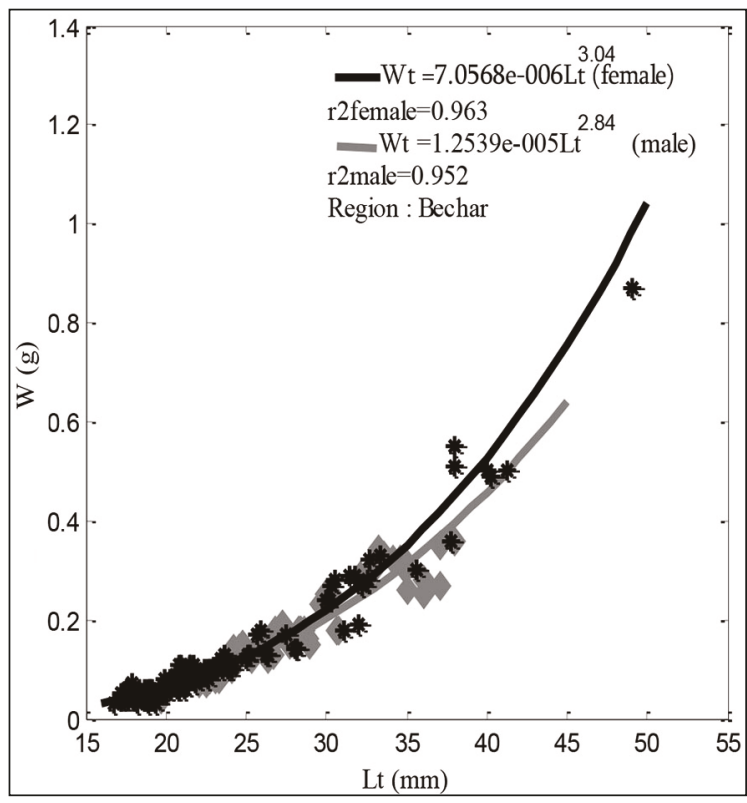

Figure 6. Length-weight relationship of male and female Gambusia affinis at Bechar.

Öztürk \& İkiz (2004). However, the sex ratio is different at Althama (1:1.1), Aian Elmajdob (1:2.5) and Ard Alahlam (1:2) in Benghazi, Libya (Eltaeeb \& Elbaraasi, 2019). According to Krumholz (1948), the sex ratio of Gambusia at birth is 1:1, but this ratio is altered due to different sampling strategies, and sam- 


\begin{tabular}{|c|c|c|c|c|}
\hline \multirow{2}{*}{ Areas } & \multicolumn{3}{|c|}{ Von Bertallanffy Equation } \\
\cline { 2 - 5 } & Female & $\Phi^{\prime}$ & Male & $\Phi^{\prime}$ \\
\hline Biskra & $\mathrm{L}_{\mathrm{t}}=67.25\left(1-\mathrm{e}^{-0.99(\mathrm{t}+0.58)}\right)$ & 3.65 & $\mathrm{~L}_{\mathrm{t}}=47.89\left(1-\mathrm{e}^{-0.90(\mathrm{t}+0.42)}\right)$ & 3.31 \\
\hline Timimoune & $\mathrm{L}_{\mathrm{t}}=62.14\left(1-\mathrm{e}^{-0.89(\mathrm{t}+0.99)}\right)$ & 3.53 & $\mathrm{~L}_{\mathrm{t}}=45.48\left(1-\mathrm{e}^{-0.97(\mathrm{t}+0.95)}\right)$ & 3.30 \\
\hline Tiaret & $\mathrm{L}_{\mathrm{t}}=63.62\left(1-\mathrm{e}^{-0.80(\mathrm{t}+0.73)}\right)$ & 3.51 & $\mathrm{~L}_{\mathrm{t}}=45.49\left(1-\mathrm{e}^{-0.99(\mathrm{t}+0.53)}\right)$ & 3.31 \\
\hline Bechar & $\mathrm{L}_{\mathrm{t}}=51.72\left(1-\mathrm{e}^{-0.72(\mathrm{t}+0.43)}\right)$ & 3.28 & $\mathrm{~L}_{\mathrm{t}}=41.75\left(1-\mathrm{e}^{-0.46(\mathrm{t}+0.13)}\right)$ & 2.90 \\
\hline
\end{tabular}

Table 1. Von Bertalanffy growth equation of Gambusia affinis for both sexes.

\begin{tabular}{|c|c|c|c|c|c|}
\hline Authors & $\mathbf{a}$ & b & r2 & Sex & Areas \\
\hline \multirow{2}{*}{$\begin{array}{c}\text { Yu Cheng et al., } \\
2018\end{array}$} & $7.13 \mathrm{e}^{-6}$ & 3.253 & 0.961 & $\mathrm{~F}$ & \multirow[t]{2}{*}{ Yangtze River, China } \\
\hline & $3.29 \mathrm{e}^{-5}$ & 2.593 & 0.763 & M & \\
\hline \multirow[t]{2}{*}{ Sibel \& Deniz, 2008} & 0.016 & 2.626 & 0.908 & $\mathrm{~F}$ & \multirow[t]{2}{*}{ Lake Adana, Turkey } \\
\hline & 0.019 & 2.474 & 0.892 & M & \\
\hline \multirow{9}{*}{ Öztürk \& İkiz, 2004} & 0.131 & 3.230 & 0.991 & $\mathrm{~F}$ & \multirow[t]{3}{*}{ Fethiye-Akgöl Turkey } \\
\hline & 0.135 & 3.006 & 0.919 & M & \\
\hline & 0.133 & 3.270 & 0.988 & $\mathrm{~F}+\mathrm{M}$ & \\
\hline & 0.123 & 3.301 & 0.987 & F & \multirow[t]{3}{*}{ Dalaman, inTurkey } \\
\hline & 0.118 & 2.673 & 0.812 & M & \\
\hline & 0.126 & 3.27 & 0.982 & $\mathrm{~F}+\mathrm{M}$ & \\
\hline & 0.130 & 3.3014 & 0.987 & $\bar{F}$ & \multirow[t]{3}{*}{ Ortaca in Turkey } \\
\hline & 0.161 & 2.6737 & 0.812 & M & \\
\hline & 0.132 & 3.2685 & 0.794 & $\mathrm{~F}+\mathrm{M}$ & \\
\hline İlhan \& Sar1, 2015 & 0.0145 & 2.945 & 0.818 & $\mathrm{~F}+\mathrm{M}$ & $\begin{array}{l}\text { Marmara lake, } \\
\text { Anatolia, Turkey }\end{array}$ \\
\hline \multirow[t]{3}{*}{ Bounaceur, 1997} & $20.8 \times 10^{-3}$ & 3.20 & 0.995 & $\mathrm{~F}+\mathrm{M}$ & Tonga lake, Algeria \\
\hline & $20.1 \times 10^{-3}$ & 3.17 & 0.996 & $\mathrm{~F}+\mathrm{M}$ & $\begin{array}{l}\text { Oubeira lake, } \\
\text { Algeria }\end{array}$ \\
\hline & $32.6 \times 10^{-3}$ & 3.19 & 0.994 & $\mathrm{~F}+\mathrm{M}$ & $\begin{array}{l}\text { Oued Bouarroug, } \\
\text { Algeria }\end{array}$ \\
\hline
\end{tabular}




\begin{tabular}{|c|c|c|c|c|c|c|}
\hline \multicolumn{2}{|c|}{ Areas } & $\mathbf{L} \infty$ & $\mathbf{K}$ & $\Phi$ & Sex & Authors \\
\hline \multirow[t]{3}{*}{ France } & Vistre & 78.33 & 0.25 & 3.19 & q & \multirow[t]{3}{*}{ Carmona-catot et al., 2014} \\
\hline & Orb & 35.81 & 2.05 & 3.42 & q & \\
\hline & Bordigou & 43.35 & 1.00 & 3.27 & q & \\
\hline \multirow[t]{5}{*}{ Spain } & Fluvia & 46.06 & 1.04 & 3.34 & q & \multirow[t]{5}{*}{ Carmona-catot et al., 2014} \\
\hline & Ter & 31.43 & 2.79 & 3.44 & q & \\
\hline & Ebro & 47.43 & 0.91 & 3.31 & q & \\
\hline & Algar & 41.71 & 1.28 & 3.35 & 우 & \\
\hline & Segura & 34.67 & 2.74 & 3.52 & q & \\
\hline \multirow[t]{2}{*}{ Hawaii } & kay & 20.51 & 1.99 & 2.92 & 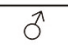 & \multirow[t]{2}{*}{ Stearns, 1983} \\
\hline & twin & 60.91 & 0.53 & 3.29 & $\pi$ & \\
\hline
\end{tabular}

Table 3. Von Bertalanffy growth parameters of Gambusia affinis reported in several areas.

pling errors, preferences and changes in their microhabitat preferences at specific stages of life of species between sex (Fernández-Delgado \& Rossomanno, 1997). The predominance of females is also due to the longer lifespan (Krumholz, 1948; Kartes \& Quignard, 1984; Fernández-Delgado, 1989).

We also observed that the proportion of females increased in the large length classes, and males in the smallest length classes, as females take longer to mature and continue to grow throughout their life (Vargas \& Sostoa, 1996), whereas males stop growing or grow very soon after the formation of the gonopodium (Krumholz, 1948).

The length-weight relationships obtained in our regions are strongly correlated $\left(\mathrm{r}^{2}\right)$, and suggest differences in growth between the sexes. The females of Biskra, Timimoune and Tiaret exhibit significant positive allometric relationship, indicating that the body weight grows slightly faster than the body length (Froese, 2006), while the males of Timimoune, Tiaret and Bechar present negative allometric growth indicating that the length increases as the cube of weight. For the males of Biskra and the females of Bechar, the isometric growth denotes as the weight and length of fish increases at the same time. Similar growth was observed for females and males of G. affinis (Table 2) in the Yangtze river in China (Yu Cheng et al., 2018), in Dalaman, and Ortaca in the Western Mediterranean region of Turkey (Öztürk \& İkiz, 2004). Additionally, in northeastern Algeria, positive growth for both sexes has been noted
(Bounaceur, 1997), while in lake Adana in Turkey (Sibel \& Deniz, 2008) and lake Marmara, Anatolia in Turkey (İlhan \& Sar1, 2015) negative growth for both sexes has been noted.

The $b$ parameter may vary depending on temperature and seasons, habitat characteristics such as salinity, availability of food resources and gonad maturity (Gonçalves et al., 1997; Taskavak \& Bilecenoglu, 2001; Özaydin et al., 2007).

The L $\infty$ values (Table 1) obtained for the females and males of Biskra, Timimoune, Tiaret and Bechar indicate that the females have a higher asymptotic length than the males. The growth parameters ( $\mathrm{L} \infty$, t0 and $\mathrm{k}$ ) have been compared with other studies (Table 3), and the asymptotic length $(\mathrm{L} \infty)$ is thereabouts similar to the studies carried out in the regions of Spain, Fluvia and Ebro areas (Carmona-catot et al., 2014). However, the L $\infty$ values are lower than those reported from Vistre, Orb and Bordigou in France (Carmona-catot et al., 2014), and Ter, Algar, Segura in Spain (Carmona-catot et al., 2014), for L $\infty$ of males, the lowest values in Kay and Twin areas in Hawaii (Stearns, 1983). According to Da Silva et al. (2020), the parameters ( $\mathrm{L} \infty$ and $\mathrm{k}$ ) apply to the assessment of growth, dynamic characteristics of populations and biomass. Furthermore, the performance index $\Phi$ ' (Table 1) shows a strong similarity between the two sexes, as these values are similar to those observed in France and Spain (Carmona-catot et al., 2014) and in Hawaii (Stearns, 1983). 


\section{CONCLUSIONS}

This study is the first data on the biological characteristics such as length-weight relationships and growth parameters of the exotic fish species $G$. affi$n i s$ in the western mainland of Algeria (Tiaret) and southwestern (Timimoune and Bechar) and northeastern Sahara (Biskra).

The length-weight relationship of $G$. affinis in these areas shows a difference in growth between the sexes indicating the isometric growth, positive and negative allometric growth. Von Bertalanffy's growth parameters differed significantly between sexes and by regional characteristics.

Growth parameters and the the length-weight relationship remain very important for any estimate of fish biomass.

\section{REFERENCES}

Alcaraz C. \& García-Berthou E., 2007. Life history variation of invasive mosquitofish (Gambusia holbrooki) along a salinity gradient. Biological Conservation, 139: 83-92. https://doi.org/10.1016/j.biocon.2007. 06.006

Arab A., 1989. Etude des peuplements d'invertébrés et de poisons appliquée à l'évaluation de la qualité des eaux et des ressources piscicoles des oueds Mouzaia et Chiffa. Thèse de Magister, Université Alger, 139 pp.

Bounaceur F., 1997. Contribution à écologie de Gambusia affinis (Baird and Girard, 1853) dans trois sites humides du parc national d'El Kala. These de magister, Ecole National Supérieur d'Agronomie, Algérie, $128 \mathrm{pp}$.

Cai X., Li G., Li F., Wang H., Zhang Y., Gu D. \& Shen Z., 2019. Length-weight relationships of three freshwater fish species from the Nandu River and Changhua River in Hainan Island, China. Journal of Applied Ichthyology, 35: 580-581. https://doi.org/ $10.1111 /$ jai.13801

Carmona-Catot G., Santos A.F.G.N., Tedesco P.A. \& Garcia-Berthou E., 2014. Quantifying seasonality along a latitudinal gradient: from stream temperature to growth of invasive mosquitofish. Ecosphere, 5: 123. http://dx. doi.org/10.1890/ES14-00163.1

Cech J.J., Massingill M.J., Vondracek B. \& Linden A.L., 1985. Respiratory metabolism of mosquitofish, Gambusia affinis: effects of temperature, dissolved oxygen, and sex difference. Environmental Biology of Fishes, 13: 297-307.

Da Silva R.S., Virgilio L.R., Corrêa F., Vieira L.J.S., 2020. Length-weight relationships of fish species from oxbow lakes on the floodplain of the middle Purus River in western Brazilian Amazon. Journal of Applied Ichthyology, 36: 256-258. https://doi.org/ 10.1111/jai.14013

Dodge Y., 2006. The Oxford Dictionary of Statistical Terms. Oxford, UK: Oxford University Press.

Eltaeeb E. \& Elbaraasi H., 2019. Populations structure of mosquitofish Gambusia affinis (Baird and Girard, 1853 ) in four different lakes in Benghazi, Libya. International Journal of Environmental Sciences \& Natural Resources, 20: 103-110. https://doi.org/10. 19080/IJESNR.2019.20.556041 0109

Fernandez-Delgado C., 1989. Life history patterns of the mosquitofish, Gambusia affinis in the estuary of the Guadalquivir river of south-west Spain. Freshwater Biology, 19: 395-404. https://doi.org/10.1111/j.13652427.1989.tb01113.x

Fernandez Delgado C. \& Rossomanno S., 1997. Reproductive biology of mosquitofish in a permanent lagoon in south-west Spain: two tactics for one species. Journal of Fish Biology, 51: 80-92.

Froese R., 2006. Cube law, condition factor and weightlength relationships: history, meta-analysis and recommendations. Journal compilation, 22: 241-253. https://doi.org/10.1111/j.1439-0426.2006.00805.x.

Gongalves J.M.S., Bentes L., Lino P.G., Ribeiro J., Carkrio A.V.M. \& Erzini K., 1997. Weight-length relationships for selected fish species of the small scale demersal fisheries of the south and southwest coast of Portugal. Fisheries Research, 30: 253-256.

Green M.V. \& Imber C.F., 1977. Applicability of Gambusia affinis to urban mosquito problems in Burlington County, New Jersey. Mosquito News, 37: 383-385.

İlhan \& Sarı H.M., 2015. Length-weight relationships of fishes in west Anatolia. Croatian Journal of Fisheries, 73: 30-32. http://dx.doi.org/10.14798/73.1.784

Kartas F. \& Quignard J.P., 1984. La fécondité des poissons téléostéens. Collection de Biologie des Milieux Marins, 5e Ed., Masson, 121 pp.

Kirkwood G.P., Aukland R. \& Zara J.S., 2001. Length frequency distribution analysis (LFDA), Version 5.0. MRAG Ltd., London, UK

Krumholtz L.A., 1948. Reproduction in the western mosquitofish Gambusia affinis. (Baird \& Girard, 1853 ) and its use in mosquito control. Ecological Monographs, 18 : 1-43. https://doi.org/10.2307/1948627

Le Cren E.D., 1951. The length-relationship and seasonal cycle in gonad weight and condition in the perch (Perca fluviatilis). Journal of Animal Ecology, 20: 201-218.

Nelson S.M. \& Keenan L.C., 1992. Use of an indigenous fish species, Fundulus zebrinus, in a mosquito abatement program: A field comparison with the 
mosquitofish Gambusia affinis. Journal of the American Mosquito Control Association, 8: 301-304.

Offill Y.A. \& Walton W.E., 1999. Comparative efficacy of the three spine stickleback (Gasterosteus aculeatus) and the mosquitofish (Gambusia affinis) for mosquito control. Journal of the American Mosquito Control Association, 15: 380-390.

Öztürk S. \& İkiz R., 2004. Some biological properties of mosquitofish populations (Gambusia affinis) living in inland waters of the western mediterranean region of Turkey. Turkish Journal of Veterinary and Animal Sciences, 28: 355-361.

Özaydın O., Uçkun D., Akalın S., Leblebici S. \& Tosunoğlu Z., 2007. Length-weight relationships of fishes captured from Izmir Bay, Central Aegean Sea. Journal of Applied Ichthyology, 23: 695-696. https://doi.org/10.1111/j.1439-0426.2007.00853.x

Pauly D. \& Munro J.L., 1984. Once more on the comparison of growth in fish and invertebrates. Fishbyte, 2: $21-21$.

Pyke G.H., 2005. A review of the biology of Gambusia affinis and G. holbrooki. Reviews in Fish Biology and Fisheries, 15: 339-365. https://doi.org/10.1007 /s11160-006-6394-x

Pyke G.H., 2008. Plague minnow or mosquito fish? A review of the biology and impacts of introduced Gambusia species. The Annual Review of Ecology, Evolution and Systematics, 39: 171-191. https:// doi.org/10.1146/annurev.ecolsys.39.110707.173451

Schwartz D., 1983. Méthodes statistiques à l'usage des médecins et des biologistes. 3éme Ed, Flammarion, $318 \mathrm{pp}$.

Sibel A.E. \& Deniz E., 2008. A preliminary research on growth features of the mosquitofish Gambusia affinis (Baird \& Girard, 1853) determined in Seyhan dam lake (Adana-Turkey). Journal of Fisheries Sciences, 2: 312-320. https://doi.org/10.3153/jfscom.mug. 200718
Stearns S.C. \& Sage R.D., 1980. Maladaption in a marginal population of the mosquito fish Gambusia affinis. Evolution, 34: 65-75. https://doi.org/10.1111/ j.1558-5646.1980.tb04789.x

Stearns S.C., 1983. The genetic basis of differences in life-history traits among six populations of mosquitofish (Gambusia affinis) that shared ancestors in 1905. Evolution, 37: 618-627.

Taskavak E. \& Bilecenoglu M., 2001. Length-weight relationships for 18 Lessepsian (Red Sea) immigrant fish species from the eastern Mediterranean coast of Turkey. Journal of the Marine Biological Association of the United Kingdom, 81: 895-896. https://doi. org/10.1017/S0025315401004805

Yu Cheng., Wen Xiong., Juan Tao., Dekui He., Kang Chen \& Yifeng Chen., 2018. Life-history traits of the invasive mosquitofish Gambusia affinis (Baird and Girard, 1853) in the central Yangtze River China. BioInvasions Records, 7: 309-318. https://doi.org/ 10.3391/bir.2018.7.3.13

Vargas M.J. \& de Sostoa A., 1996. Life history of Gambusia holbrooki (Pisces, Poeciliidae) in the Ebro delta (NE Iberian Peninsula). Hydrobiologia, 341: 215-224. https://doi.org/10.1007/BF00014686

Von Bertalanffy L., 1938. A quantitative theory of organic growth (inquires on growth laws II). Human Biology, 10: 181-213.

Vondracek B., Wayne A. \& Cech J., 1988. Growth and reproduction of the mosquitofish, Gambusia affinis, in relation to temperature and ration level. Environmental Biology of Fishes, 21: 45-57.

Walton W.E., 2007. Larvivorous fish including Gambusia. Journal of the American Mosquito Control Association, 23: 184-220. https://doi.org/10.2987/8756971X(2007)23[184:LFIG]2.0.CO;2.

Wootton R.J., 1990. Ecology of Teleost Fishes. 1st Ed., London Chapman \& Hall, 343 pp. 
. 